\title{
Isolation and Partial Characterization of a Plasmid in the Extremely Halophilic Archaebacterium Halococcus morrhuae CCM 537
}

\author{
By CARLOS G. MONTERO, ANTONIO VENTOSA,* JOAQUIN J. NIETO \\ AND FRANCISCO RUIZ-BERRAQUERO \\ Department of Microbiology, Faculty of Pharmacy, University of Sevilla, Sevilla, Spain
}

(Received 4 January 1988; revised 23 May 1988)

\begin{abstract}
The extremely halophilic archaebacterium Halococcus morrhuae CCM 537 was found to contain a plasmid, pHM2, of $6.0 \mathrm{~kb}$. A restriction map was constructed. Southern hybridization of pHM2 DNA to DNA extracted from other Halococcus sp. strains revealed the presence of a similar plasmid in one other strain. A plasmid of Halobacterium trapanicum shared common sequences with pHM2. Other plasmids from halobacteria displayed no homology with pHM2. The characterization of pHM2 may make it useful for the development of cloning vectors for extremely halophilic archaebacteria.
\end{abstract}

\section{INTRODUCTION}

The majority of extremely halophilic bacteria are included in one of the three primary phylogenetic groupings, the so-called archaebacteria (Woese \& Fox, 1977). They can grow in saline media with salt concentrations ranging from $12 \%(\mathrm{w} / \mathrm{v})$ to saturation, and grow optimally at approximately $25 \%(\mathrm{w} / \mathrm{v})$ total salts (Kushner, 1985).

Several plasmids have been identified in halobacteria (Paton et al., 1981; Pfeifer et al., 1981 a; Ebert et al., 1984; Tindall et al., 1984; Ross \& Grant, 1985; Gutiérrez et al., 1986). The main plasmid species from these extremely halophilic rods are usually large, especially those from Halobacterium halobium ( $\mathrm{pHH} 1, \mathrm{pHH} 2, \mathrm{pHH} 3$ ), Halobacterium salinarium (pHHR1) and Halobacterium cutirubrum ( $\mathrm{pHC}$ ), but smaller plasmids in Haloferax volcanii, Halobacterium trapanicum and Halobacterium sp. strains SB3, GN101 and GRB have also been described (Pfeifer, 1988). Plasmids of Halobacterium halobium and closely related strains show extensive homology but have a high degree of structural variation (Pfeifer et al., 1981b; Sapienza \& Doolittle, 1982). Two small plasmids from Halobacterium sp. strains SB3 and GRB have been studied in detail and proposed as potential cloning vectors for halobacteria (Ebert $e t$ al., 1984).

The majority of molecular studies of these bacteria have been done in halobacteria, but recent work has examined the genus Halococcus (Leffers \& Garret, 1984; Montero et al., 1988). As yet, no studies have been reported on the presence of plasmids in Halococcus morrhuae (Ross \& Grant, 1985; Pfeifer, 1988). The paucity of information may be attributed to the fact that halococci display some of the toughest envelopes known among bacteria, being very difficult to break, though they can be disrupted by shaking with glass beads (Schleifer et al., 1982).

Here we report the isolation and partial characterization of a small plasmid from Halococcus morrhuae CCM 537 (type strain). The homology of this plasmid to other halobacterial plasmids, as well as its occurrence in other halococci recently isolated, was tested.

\section{METHODS}

Bacterial strains. Halococcus morrhuae CCM 537 was used as reference strain. Halococcus sp. N-207 and Halococcus sp. P-423 were isolated from ponds of salterns located in Alicante, Spain (Montero et al., 1988). Halobacterium halobium NRC 34020, Halobacterium trapanicum CHB-83, Haloferax volcanii NCMB 2012, and Halobacterium sp. SB3 were also used. 
For molecular cloning experiments, Escherichia coli $\mathrm{K} 12$ strain $\mathrm{D} 1210\left(\mathrm{r}_{\mathrm{k}}-\mathrm{m}_{\mathrm{k}}-\right.$ recA13 ara-14 proA2 lac Y1 galK2 supE44 lac $^{\mathrm{Q}}$ ) was used as host and was kindly supplied by Dr F. Pfeifer, Max Planck Institut für Biochemie, FRG.

Growth conditions. All halobacteria and halococci strains were grown in HM medium (Ventosa et al., 1982), containing $(\%, w / v)$ : yeast extract (Difco), 1 ; Proteose-peptone no. 3 (Difco), $0.5 ;$ glucose, $0 \cdot 1$; Bacto agar (Difco), 2. This medium was supplemented with a balanced mixture of sea salts giving a final concentration of $25 \%(\mathrm{w} / \mathrm{v})$ (Rodríguez-Valera et al., 1980). E. coli was grown in Luria medium (Maniatis et al., 1982) or in M9 medium (Miller, 1972). Tetracycline was added when required as a filter-sterilized concentrate in water to a final concentration of $25 \mathrm{mg} \mathrm{l}^{-1}$. All cultures were incubated at $37^{\circ} \mathrm{C}$.

Plasmid isolation. Cultures of $H$. morrhuae were incubated for one week. Glycine was then added to the growth medium to a final concentration of $1 \%(w / v)$ and the culture was incubated for another $2 \mathrm{~d}$. The cells were harvested by centrifugation at $15000 \mathrm{~g}$ for $10 \mathrm{~min}$ in a Sorvall GSA rotor and resuspended in distilled water. Cell lysis was achieved by the addition of $20 \%(w / v)$ Sarkosyl (Sigma) in water to a final concentration of $1 \%(w / v)$. The cell lysate was centrifuged at $20000 \mathrm{~g}$ for $20 \mathrm{~min}$. To the supernatant were added 2 vols of ethanol and $5 \mathrm{M}-\mathrm{NaCl}$ to a final concentration of $0.1 \mathrm{M}$. The mixture was left for $10 \mathrm{~min}$ in dry ice, and then centrifuged at $12000 \mathrm{~g}$ for $10 \mathrm{~min}$. The pellet was resuspended in Tris/EDTA (10:1) buffer. Plasmid DNA was obtained from CsCl/ethidium bromide gradients after centrifugation in a Beckman Ti 50 rotor at $55000 \mathrm{~g}$ for $2 \mathrm{~d}$. Plasmids were separated by electrophoresis at $4 \mathrm{~V} \mathrm{~cm}^{-1}$ for $16 \mathrm{~h}$ on $1.0 \%(w / v)$ agarose vertical gels in Tris/acetate EDTA buffer. A small plasmid was electroeluted from the gels by the direct method of Maniatis et al. (1982). Plasmid isolation from halobacteria was achieved as previously described (Pfeifer et al., 1981 a).

Restriction endonuclease digestion and gel electrophoresis. Restriction endonuclease digestions of chromosomal and plasmid DNA were done under the conditions recommended by the manufacturers of the enzymes used. DNA fragments were separated by electrophoresis at $4 \mathrm{~V} \mathrm{~cm}{ }^{-1}$ for $16 \mathrm{~h}$ on $1 \cdot 0-2 \cdot 0 \%(\mathrm{w} / \mathrm{v})$ agarose horizontal gels. The gels were run in Tris/acetate/EDTA buffer, stained with ethidium bromide $\left(5 \mu \mathrm{g} \mathrm{ml}^{-1}\right.$ for $\left.10 \mathrm{~min}\right)$ and destained with water (30-60 min). Restriction enzymes were purchased from Boehringer. Agarose type II was from Sigma. ClaI-digested $\phi \mathrm{H}$ DNA was obtained from Dr F. Pfeifer.

Plasmids, ligation, transformation and plasmid constructions. The small plasmid isolated from $H$. morrhuae CCM 537 was cleaved with EcoRI, and the resulting fragments were ligated into the EcoRI site of pUM121 (Nilsson et al., 1983) by standard techniques (Maniatis et al., 1982) and recovered in E. coli. Two recombinant plasmids, each one harbouring a different EcoRI fragment from pHM2, were used for detailed mapping of restriction sites on the plasmid. General molecular methods and experiments specific to $E$. coli were used according to Maniatis et al. (1982). pBR322 was obtained from Boehringer.

Hybridization. Electrophoretically separated and stained DNA fragments were denatured in the gel by submersion for $30 \mathrm{~min}$ in $0.5 \mathrm{M}-\mathrm{NaOH}$ containing $1.5 \mathrm{M}-\mathrm{NaCl}$. The alkali was neutralized by gentle agitation for $30 \mathrm{~min}$ in $0.5 \mathrm{M}$-Tris $/ \mathrm{HCl}, \mathrm{pH} 7.2$, containing $1.5 \mathrm{M}-\mathrm{NaCl}$. Transfer of DNA to nitrocellulose membranes (Schleicher \& Schüll), hybridization with nick-translated plasmid and subsequent washing, first with $2 \times$ SSC containing $0.1 \% \operatorname{SDS}\left(2 \times 15 \mathrm{~min}\right.$ at $\left.68^{\circ} \mathrm{C}\right)$ and then with $0.2 \times \operatorname{SSC}\left(2 \times 15 \mathrm{~min}, 68^{\circ} \mathrm{C}\right)$, were done according to Southern (1975). Nick translation of plasmid DNA (Rigby et al., 1977) generated ${ }^{32}$ P-labelled DNA with a specific radioactivity of $7.4 \mathrm{MBq}(\mu \mathrm{g} \mathrm{DNA})^{-1}$.

\section{RESULTS AND DISCUSSION}

\section{pHM2 from H. morrhuae CCM 537}

Standard lysing procedures for other bacteria were not suitable for $H$. morrhuae. We were unable to obtain DNA from cells treated with lysozyme, sarkosyl, SDS, Triton X-100 or sodium deoxycholate, or from cells disrupted by mechanical methods. Other methods previously described for isolation of DNA from halobacteria (Pfeifer et al., 1981a) or from halococci (Kocur \& Bohacek, 1972; Leffers \& Garrett, 1984) also were not suitable. Addition of glycine to culture media impairs cell wall biosynthesis and results in a weakened cell wall (Owen \& Pitcher, 1985). Accordingly, we added glycine to the growth media to see if it facilitated extraction and purification of DNA from these organisms (see Methods). Using this method of cell culture, we were subsequently able to isolate both total DNA and plasmid DNA from strains of the genus Halococcus. In this study, we tested the type strain H. morrhuae CCM 537. Two plasmids (pHM1 and $\mathrm{pHM} 2$ ) were detected in this strain. The approximate molecular masses of these plasmids were 48 and $6 \mathrm{~kb}$, respectively. The small plasmid, pHM2 was selected for further study because of its low molecular mass, which makes it potentially useful for the development of cloning vectors. 


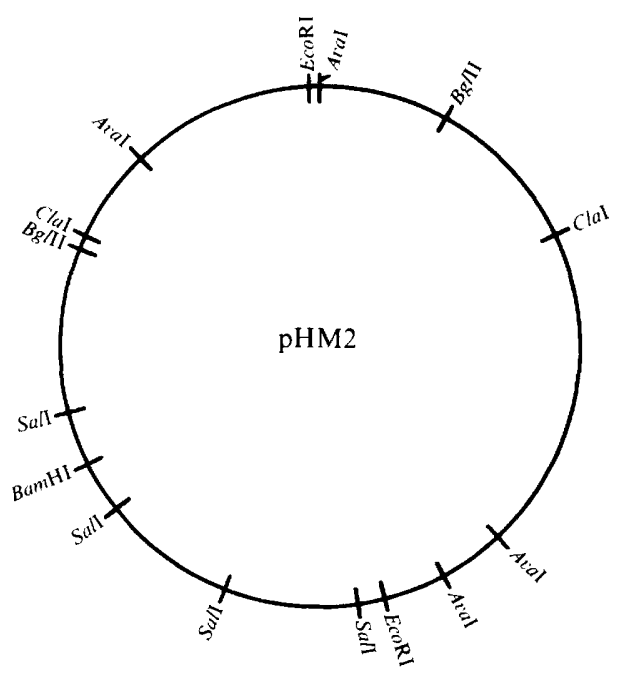

Fig. 1. Restriction map of pHM2.

Restriction analysis with $E c o$ RI of pHM2 from $H$. morrhuae CCM 537 showed two fragments. These two $E c o$ RI restriction fragments were ligated into the $E c o$ RI site of the plasmid vector pUM121, and the ligation mixtures were used to transform E. coli K12 strain D1210. Recombinant plasmids were isolated from $\mathrm{Tc}^{r}$ transformants and were named pCM1 and pCM2. The inserted fragments in pCM1 and pCM2 were 3.2 and $2.8 \mathrm{~kb}$ in size, respectively, corresponding to the two EcoRI fragments of pHM2. The orientation of these fragments in pHM2 was deduced from single and double digestions of pHM2 with EcoRI and ClaI. The rest of the map (Fig. 1) was obtained from the analysis of pCM1 and pCM2. The following restriction enzymes were used : $A l u \mathrm{I}, A v a \mathrm{I}, B a m \mathrm{HI}, B g l \mathrm{II}, C l a \mathrm{I}, E c o \mathrm{RI}, E c o \mathrm{RV}, H a e I I I, H i n d I I I$, HpaII, PstI, SalI, TaqI and XhoI. More than five restriction enzyme sites each for AluI, HaeIII, $H$ PaII and TaqI were found on pHM2, but these have not been mapped. No sites were found for EcoRV, HindIII, PstI or XhoI. It should be noted that of the restriction enzymes tested only BamHI cleaved pHM2 once (Fig. 1).

An ideal plasmid from which to develop a cloning vector for halobacteria would : (i) be stably maintained in halobacteria, (ii) be small, (iii) be present in high copy number, (iv) contain unique restriction enzyme sites for cloning purposes, and, (v) possess a selectable marker (Old \& Primrose, 1985). The plasmid identified, pHM2, satisfies conditions (ii), (iii) and (iv).

\section{Southern blot hybridization analysis}

pHM2 was ${ }^{32} \mathrm{P}$-labelled and used to probe total DNA isolated from other strains of the genus Halococcus (Fig. 2) and to determine its relationship to plasmids harboured by other halobacteria (Fig. 3). Genomic DNA from Halococcus strains P-423 and N-207 was digested with SstI. Probe DNA hybridized only to N-207 DNA, and in this case the band pattern obtained was indistinguishable from that seen with $H$. morrhuae CCM 537 from which pHM2 originated. These results indicate that H. morrhuae CCM 537 and Halococcus sp. N-207 harbour the same plasmid. In a previous numerical taxonomic study (Montero et al., 1988) both strains were included in the same phenon, despite the fact that they were isolated from different places (one is a culture collection strain, the other was isolated from salterns in Alicante, Spain). Halococcus sp. P-423 has been placed in a different phenon, with very different phenotypic features from CCM 537. It is worth noting that the former strain shows a completely different genomic pattern from the latter.

To test whether pHM2 has sequences in common with other halobacterial plasmids, we examined four characterized halobacterial plasmids (Pfeifer et al., 1981a). One plasmid from 


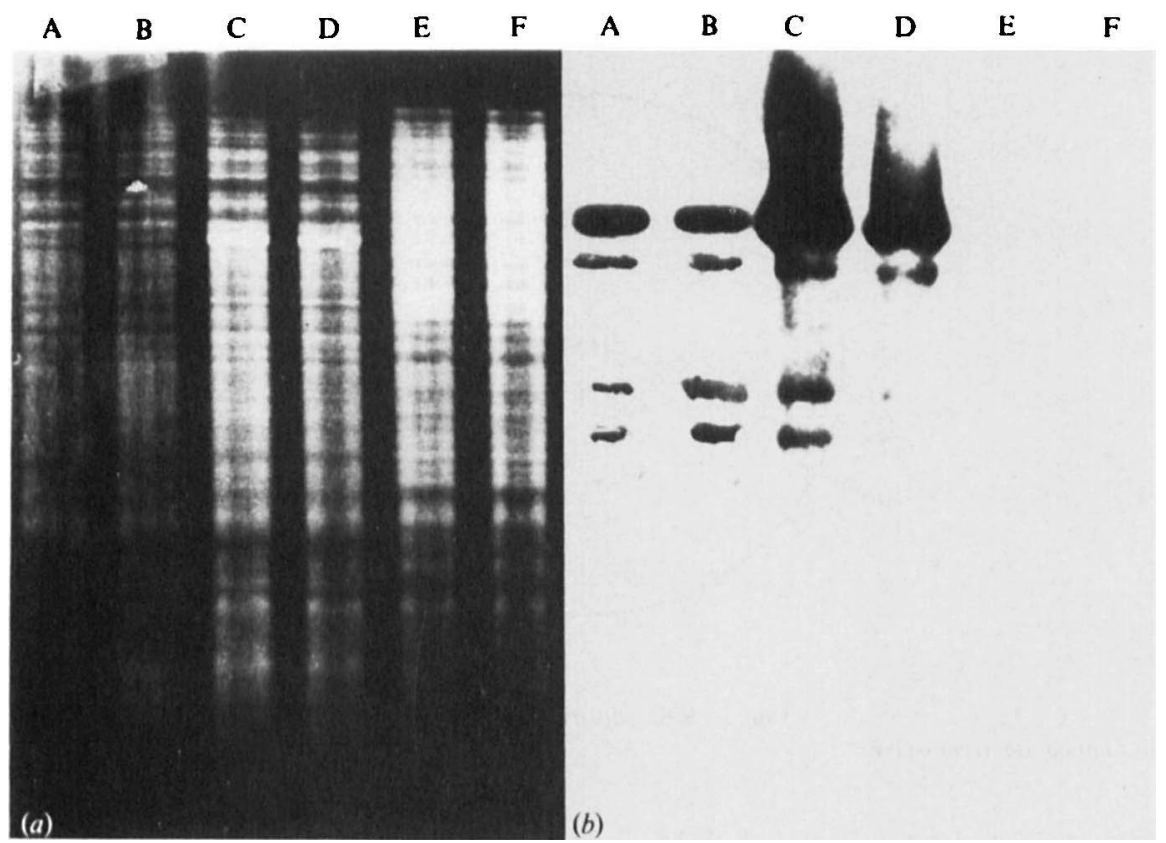

Fig. 2. (a) DNA fragment patterns of Halococcus sp. genomic DNA after digestion with the restriction enzyme SstI. (b) Hybridization pattern of ${ }^{32} \mathrm{P}$-labelled pHM2 probe DNA to Halococcus $\mathrm{sp}$. SstIdigested DNA. Tracks: A and B, Halococcus morrhuae CCM 537; C and D, Halococcus sp. N-207; $\mathrm{E}$ and F, Halococcus sp. P-423.

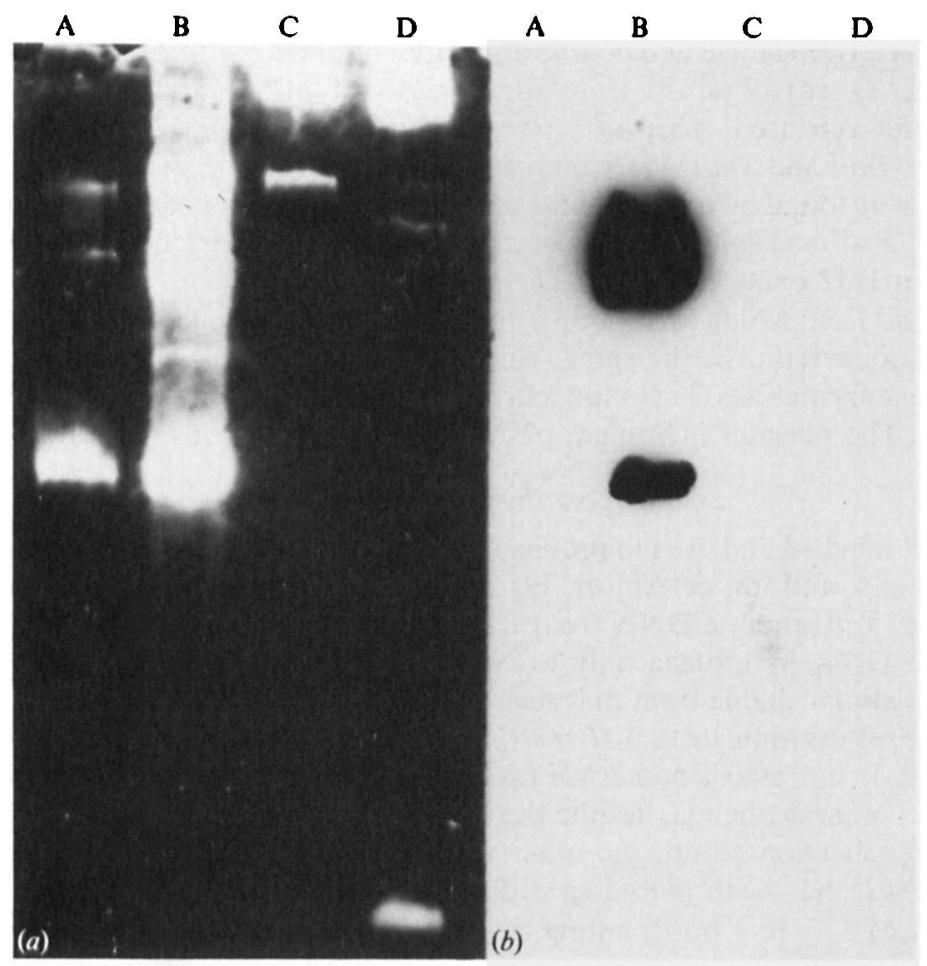

Fig. 3. (a) Halobacterial plasmids. (b) Hybridization of ${ }^{32} \mathrm{P}$-labelled pHM2 to halobacterial plasmids. Plasmids were isolated from: A, Haloferax volcanii NCMB 2012; B, Halobacterium trapanicum CHB-83; C, Halobacterium halobium NRC 34040; D, Halobacterium sp. strain SB3. 
Halobacterium trapanicum displayed homology with pHM2 (Fig. 3). This finding may indicate plasmid exchange in this archaebacterial group. Gene exchange by conjugation (Mevarech \& Werczberger, 1985) and by transfection (Cline \& Doolittle, 1987) have been reported which indicates that archaebacteria share similar genetic exchange systems to other bacteria.

We are grateful to F. Pfeifer for providing plasmids, strains and advice. This investigation was supported by grants from the Comision Asesora para el Desarrollo de la Investigación Científica y Técnica and from the Junta de Andalucía.

\section{REFERENCES}

Cline, S. W. \& Doolittle, W. F. (1987). Efficient transfection of the archaebacterium Halobacterium halobium. Journal of Bacteriology 169, 1341-1344.

Ebert, K., Goebel, W. \& Pfeifer, F. (1984). Homologies among heterogeneous extrachromosomal DNA populations in Halobacterium halobium and four new halobacterial isolates. Molecular and General Genetics 194, 91-97.

Gutierrez, M. C., Garcia, M. T., Ventosa, A., Nieto, J. J. \& Ruiz-BerRaquero, F. (1986). Occurrence of megaplasmids in halobacteria. Journal of Applied Bacteriology 61, 67-71.

KoCUR, M. \& BoHACEK, J. (1972). DNA base composition of extremely halophilic cocci. Archiv für Mikrobiologie 82, 280-282.

KUSHNER, D. J. (1985). The Halobacteriaceae. In The Bacteria, vol. 8, pp. 171-214. Edited by C. R. Woese \& R. S. Wolfe. London: Academic Press.

LEFFERS, H. \& GaRretT, A. (1984). The nucleotide sequence of the $16 \mathrm{~S}$ ribosomal RNA gene of the archaebacterium Halococcus morrhuae. EMBO Journal 3, 1613-1619.

Maniatis, T., Fritsch, E. F. \& SambrooK, J. (1982). Molecular Cloning, a Laboratory Manual. Cold Spring Harbor, NY: Cold Spring Harbor Laboratory.

MeVARECH, M. \& WerCZberGeR, R. (1985). Genetic transfer in Halobacterium volcanii. Journal of Bacteriology 162, 461-462.

Miller, J. H. (1972). Experiments in Molecular Genetics. Cold Spring Harbor, NY: Cold Spring Harbor Laboratory.

Montero, C. G., Ventosa, A., Rodriguez-Valera, F. \& RuIZ-BerRaQuero, F. (1988). Taxonomic study of non-alkaliphilic halococci. Journal of General Microbiology 134, 725-732.

NilsSon, B., UhLEN, M., JosephSon, S., Gatenbeck, S. \& Philipson, L. (1983). An improved positive selection plasmid vector constructed by oligonucleotide mediated mutagenesis. Nucleic Acids Research 11, 8019-8030.

OLD, R. W. \& Primrose, S. B. (1985). Principles of Gene Manipulation. An Introduction to Genetic Engineering, 3rd edn. Oxford: Blackwell Scientific Publications.

Owen, R. J. \& Pitcher, D. (1985). Current methods for estimating DNA base composition and levels of DNA-DNA hybridization. In Chemical Methods in Bacterial Systematics. Edited by M. Goodfellow \& D. E. Minnikin. London: Academic Press.

Paton, E. B., Khodkova, E. M., Gurieva, N. M. \& Sverdlov, E. D. (1981). Plasmid from various strains of Halobacterium halobium. Bioorganicheskaya Khimiya 7, 1532-1537.
Pfeifer, F. (1988). Genetics of halobacteria. In Halophilic Bacteria, pp. 105-133. Edited by F. Rodriguez-Valera. Boca Raton: CRC Press.

Pfeifer, F., Weidinger, G. \& Goebel, W. (1981 $a$ ). Characterization of plasmids in halobacteria. Journal of Bacteriology 145, 369-374.

Pfeifer, F., Weidinger, G. \& Goebel, W. (1981 $b$ ). Genetic variability of Halobacterium halobium. Journal of Bacteriology 141, 375-381.

Rigby, W. J., Dieckman, M., Rhodes, C. \& Berg, P. (1977). Labelling deoxyribonucleic acid to high specific activity in vitro by nick-translation with DNA polymerase I. Journal of Molecular Biology 113, 237-251.

Rodriguez-VAlera, F., RUIZ-BERRAQuero, F. \& RAMOS-CORMENZANA, A. (1980). Isolation of extremely halophilic bacteria able to grow in defined inorganic media with single carbon sources. Journal of General Microbiology 119, 535-538.

Ross, H. N. M. \& GRaNT, W. D. (1985). Nucleic acid studies on halophilic archaebacteria. Journal of General Microbiology 131, 165-173.

SAPIEnZA, C. \& Doolittle, W. F. (1982). Unusual physical organization of the Halobacterium genome. Nature, London 295, 384-389.

SChleifer, K. H., Steber, J. \& MAYeR, H. (1982). Chemical composition and structure of the cell wall of Halococcus morrhuae. Zentralblatt für Bakteriologie, Parasitenkunde, Infecktionskrankheiten und $\mathrm{Hy}$ giene (Abteilung I) C3, 171-176.

SoutherN, E. M. (1975). Detection of specific sequences among DNA fragments separated by gel electrophoresis. Journal of Molecular Biology 98, 503-517.

Tindall, B. J., Ross, H. N. M. \& Grant, W. D. (1984). Natronobacterium gen. nov. and Natronococcus gen. nov., two new genera of haloalkaliphilic archaebacteria. Systematic and Applied Microbiology $5,41-57$.

Ventosa, A., Quesada, E., Rodriguez-Valera, F., Ruiz-BerRaquero, F. \& Ramos-Cormanzana, A. (1982). Numerical taxonomy of moderately halophilic Gram-negative rods. Journal of General Microbiology 128, 1959-1968.

WOESE, C. R. \& Fox, G. E. (1977). Phylogenetic structure of the prokaryotic domain: the primary kingdoms. Proceedings of the National Academy of Sciences of the United States of America 74, 50885090. 